\title{
A comparative study of electronic cigarette vapour extracts on airway- related cell lines in vitro
}

\author{
Laura J Leslie ${ }^{\mathrm{a}}$, Pranav Vasanthi Bathrinarayanan ${ }^{\mathrm{a}}$, Pamela Jackson ${ }^{\mathrm{b}} \underset{\ddagger}{ }$, Justin A \\ Mabiala Ma Muanda ${ }_{\ddagger} \mathrm{b}$, Ross Pallett $\mathrm{b}_{\ddagger}$, Christopher JP Stillman ${ }_{\ddagger}^{\mathrm{b}}$, Lindsay J \\ Marshall $^{\mathrm{b}}$
}

\#-These authors contributed equally to the work

$a-$ School of Engineering and Applied Science, Aston University, Birmingham. B4 7ET.

United Kingdom.

$b-$ School of Life and Health Sciences, Aston University, Birmingham. B4 7ET. United Kingdom.

E-mail addresses; l.j.leslie@aston.ac.uk; vasanthp@aston.ac.uk; jacksop1@aston.ac.uk; mabialaa@aston.ac.uk; pallettr@aston.ac.uk; stillmac@aston.ac.uk;

l.marshall@aston.ac.uk

Dr Laura J Leslie

Mechanical Engineering and Design, School of Engineering and Applied Science, Aston University, Birmingham. B4 7ET. UK.

e-mail: 1.j.leslie@ aston.ac.uk

Tel: ++44 1212043747 


\section{A comparative study of electronic cigarette vapour extracts on airway- related cell lines in vitro}

The use of electronic cigarettes (ECs) is rapidly increasing worldwide, however scientific evidence regarding EC cytotoxicity is limited. The aim of this study was to evaluate the acute cytotoxicity of EC vapour extract (ECE) on airway-related cells in vitro.

Cigarette smoke extract (CSE), vapour extract of fifteen brands/flavours of ECs and the extract from the E-vehicle (propylene glycol and glycerine) was collected. Extracts, in concentrations of $100 \%$ to $12.5 \%$, were added to human bronchial epithelial (BEAS2B, IB3-1 and C38), fibroblast (Wi-38) and macrophage (J774 and THP-1) cell lines. Viability was assessed after 24 hours using a standard XTT assay. Viability of less than $70 \%$ of control (no extract) was considered cytotoxic according to UNI EN ISO 109935 standards.

CSE displayed a concentration-dependent influence on cell viability across all four cell lines with $100 \%$ producing the most toxic effect, therefore validating the model. ECEs reduced viability although this was not correlated with nicotine content or the Evehicle. However, several flavours proved cytotoxic, with variation between different brands and cell lines.

These data indicate that not all ECs are the same and that use of a particular flavour or brand may have differing effects. The cell line used is also an important factor. More research is crucial to ascertain the health effects of different ECs before they can be accepted as a safe alternative to tobacco cigarettes.

Keywords: Electronic cigarettes; airways; cytotoxicity; epithelials; in vitro models 


\section{Introduction}

Electronic cigarettes (EC) first emerged onto the market in China in 2004 and entered the US market in 2007 (Regan et al. 2013). Advertised as a safe alternative to traditional tobacco cigarettes, EC were soon introduced across different countries and their market has steadily risen. According to the UK's public health charity, Action on Smoking and Health (ASH), 2.6 million adults in Great Britain currently use EC (ASH 2015). There has been a rapid global progression amongst high and low income countries, with EC use stabilising at around $17 \%$ of adult smokers, although awareness of these products is much higher, according to data pulled together in a recent Public Health England report (Britton and Bogdanovica 2014).

The body of research performed on the acute and chronic effects of ECs on human health is limited (Breland et al. 2014). There are a number of challenges associated with EC research. The lack of a standardised testing protocol to evaluate different products means that there is no consensus between academic researchers, manufacturers and stake-holders (Orr 2014). Proper toxicological evaluations of ECs by the regulatory bodies are also lacking.

The liquid component of EC, known as E-liquid, has been studied, and these reports show that there are a number of variations and complications in terms of these analyses (e.g. Bahl et al. (2012) and Misra et al. (2014)). Unlike tobacco cigarettes, which have defined nicotine yields on the packaging, the nicotine content of E-liquids is simply labelled as 'low', 'medium', or 'high'; the precise concentration is not defined. In some cases this has been found to be inaccurate (Cameron et al. 2014) with E-liquids labelled as 'nicotine free' containing detectable levels of nicotine (FDA 2014). 
Harmful, tobacco specific nitrosamines (TSNA), such as 4-(methylnitrosamino)-1-(3pyridyl)-1-butanone (NNK) and N9-nitrosonor-nicotine (NNN) (Goniewicz et al. 2014), along with the minor tobacco alkaloids, anabasine and myosmine (FDA 2014), have been shown to be present in EC vapours, at levels such that EC smoking ("vaping") can result in equivalent formaldehyde exposure as cigarette smoking (Goniewicz, Knysak, Gawron, Kosmider, Sobczak, Kurek, Prokopowicz, Jablonska-Czapla, Rosik-Dulewska and Havel 2014). The lack of any clear labelling and the apparent differences between the concentrations of components in identical bottles of EC refill fluids (Behar et al. 2014) complicate the evaluation of different ECs, EC liquids and the volatiles released in EC vapour. The contents of EC and EC liquid (for refillable EC) and the efficiency of vapourising differ between different brands, flavours, manufacturers and EC designs and therefore make comprehensive analysis of potential adverse health effects of EC very challenging.

Studies of EC vapour extract (ECE) on human cells are extremely limited. Data thus far predominantly includes work performed on non-human cell lines including rat cardiomyoblasts (Farsalinos, Romagna, Allifranchini, et al. 2013) and mouse fibroblasts (Romagna et al. 2013). There have been some studies using whole EC vapour in cell exposure experiments. In a recent study funded by British American Tobacco, Nielson et al. (2015), used commercially available cell culture models of the human airways to examine ECE toxicity in comparison to tobacco cigarette exposure. The study concluded that EC were less toxic than tobacco but the limitations of the study were that ECE exposure was limited to the same flavoured EC with two different nicotine concentrations. 
Exposure to EC contents, in the form of the E-liquid, has been studied in vitro. For example, Bahl et al (2012) exposed various cell types, including human pulmonary fibroblasts, to refill fluids from three different manufacturers and found no correlation between cytotoxicity and nicotine content. Importantly, this study did show differences in IC50 for doses of $0-1 \%$ of the refills for different brands/flavours and different susceptibility for different cell types. This association of varying cytotoxicity with the flavourings used has been verified with other studies (Farsalinos, Romagna, Allifranchini, Ripamonti, Bocchietto, Todeschi, Tsiapras, Kyrzopoulos and Voudris 2013). Cinnamon flavoured EC liquids in particular have been found to be relatively more cytotoxic than other flavours tested (Bahl, Lin, Xu, Davis, Wang and Talbot 2012, Behar, Davis, Wang, Bahl, Lin and Talbot 2014).

The main aim of this research is to study the effects of ECE on cultured human bronchial epithelial cells and macrophages in-vitro, something which to date has not been shown in the literature. Here we analyse the effects of a large variety of EC brands, nicotine concentrations and flavourings, as well as the vehicle which delivers these constituents, on epithelial cells, fibroblasts and macrophages, in order to establish useful data on the potential cytotoxicity of these devices.

\section{Materials and Methods}

\section{Cigarettes and ECs}

A number of branded ECs were purchased from consumer websites. Marlboro Reds (Philip Morris International, New York, USA) were employed as standard tobacco cigarettes for validation purposes. The anonymised EC brands are listed in table 1, along with the information provided by the manufacturer on nicotine content and other additives. 


\section{Cell Culture}

Seven cell lines in total were used in the current work to investigate the toxicity of EC; Four human derived bronchial epithelial cell lines, BEAS-2B, IB3-1, C38 and CALU-3, two macrophage cell lines, namely J774, a mouse macrophage and THP-1 a monocyte-derived macrophage and Wi-38, a human derived fibroblast cell line. These were selected in order to test the effects of ECE on the most relevant cell types likely to be affected by vaping; namely the bronchial epithelial cells lining the upper respiratory tract, the underlying fibroblast cells, and the macrophages, defensive cells that patrol the airways to maintain sterility and minimise damage. All cell lines were originally available from the ATCC (LGC Standards, Middlesex, UK). All cell culture consumables were from Thermo Scientific Ltd (Loughborough, UK).

Epithelial cell lines were all maintained in DMEM-F12 (1:1 ratio of Dulbecco's Modified Eagle's Medium and Ham's F12) supplemented with $50 \mathrm{U} / \mathrm{mL}$ penicillin, $50 \mu \mathrm{g} / \mathrm{mL}$ streptomycin and 10\% (v/v) serum (FBS). Fibroblasts were cultured in EMEM (Eagle's minimum essential medium) supplemented with $50 \mathrm{U} / \mathrm{mL}$ penicillin, $50 \mu \mathrm{g} / \mathrm{mL}$ streptomycin and $10 \%(\mathrm{v} / \mathrm{v})$ serum (FBS). J774 and THP-1 cell culture medium consisted of RPMI 1640 (Roswell Park Memorial Institute medium) supplemented with 2 mM L-Glutamine, 50 U/mL penicillin, $50 \mu \mathrm{g} / \mathrm{mL}$ streptomycin and $10 \%$ (v/v) serum (FBS). When using the THP-1 cell line the cells were cultured for $48 \mathrm{~h}$ with $250 \mathrm{~nm}$ Phorbol 12-Myristate 13-Acetate (PMA) at $2 \times 105$ prior to exposure to induce differentiation to macrophage-like cells (Thomas et al. 2013). All cell lines were cultured at $5 \% \mathrm{CO} 2$ and $37^{\circ} \mathrm{C}$. Culture medium was changed three times per week and all cell cultures were examined microscopically daily in order to monitor 
any changes in viability (reduction in adherence) or morphology that would indicate bacterial infection.

\section{Extract Collection}

Cigarette Smoke Extract (CSE), E-vehicle Extract (EVE) and EC vapour extract (ECE) were obtained based on accepted methodologies (Carp and Janoff 1978). The technique allows the water-soluble components of the ECs and cigarette to be applied to the cell cultures.

However, the water-insoluble components in this methodology are not considered. In brief, a lit cigarette or activated EC was attached to the inflow tube of the apparatus (Figure 1). A $12 \mathrm{~V}$ power supply unit (Manson Engineering Industrial Ltd, Hong Kong) was used to activate a diaphragm pump (Gardner Denver Ltd., Germany) and draw the cigarette smoke/EC vapour through the inflow tube and into the small sterile glass bottle, containing $10 \mathrm{~mL}$ of appropriate sterile cell culture medium. This was performed over a time period of 2 seconds, drawing through $35 \mathrm{~mL}$, followed by a pause of 28 seconds before repeating (ISO 1991). Flow rates were monitored and regulated via an integral flow meter (Key Instruments, Trevose, PA, USA). The time taken to smoke the whole cigarette completely was approximately 7 minutes involving 14 puffs. ECE was obtained in a similar process involving the same puff rate, puff duration and total number of puffs as CSE. Individual sets of tubes and bottles were used for either cigarettes or ECs to minimise the chance of cross contamination. All bottles and tubes were thoroughly washed and autoclaved between uses. The CSE and ECE were collected (100\% concentration) and were serially diluted in medium to dilutions of $50 \%, 25 \%$ and $12.5 \%$. The EVE was collected at $100 \%$ concentration and was not diluted. All extracts were collected shortly before (less than one hour) being applied to the cells. 


\section{Exposure of cell lines to CSE, EVE or ECE}

For experiments using the epithelial cells, $1 \mathrm{~mL}$ of $3 \times 105$ cells $/ \mathrm{mL}$ were seeded into each well of a $24-w e l l$ plate and incubated overnight at $5 \% \mathrm{CO} 2,37^{\circ} \mathrm{C}$. Fibroblasts were plated in a similar fashion except that the seeding density was $1 \times 105$ cells $/ \mathrm{mL} /$ well and for the monocytes it was $2 \times 105$ cells/mL/well. After twenty four hours, after the cells had formed a confluent monolayer, the existing medium was aspirated from each well and immediately replaced with medium containing the CSE, EVE or ECE. $1 \mathrm{~mL}$ of each dilution of CSE or ECE $(100 \%, 50 \%, 25 \%$ and $12.5 \%)$ was added into the appropriate wells. Control samples were cells submerged in untreated medium. Plates were incubated at $37^{\circ} \mathrm{C}$ and $5 \% \mathrm{CO} 2$ for twenty four hours.

\section{Cell viability analysis}

XTT was made up to $1 \mathrm{mg} / \mathrm{mL}$ in PBS and added to $1 \mathrm{mM}$ menadione in acetone at a ratio of 12.5:1. $250 \mu \mathrm{L}$ of this solution was added to each well containing the extracts or untreated medium and incubated at $37^{\circ} \mathrm{C}$ for 2 hours. After this time, $100 \mu \mathrm{L}$ of the supernatant from each well was transferred in triplicate to a 96 well microplate and the absorbance read at 450 nm using a spectrophotometer (MultiSkan, ThermoScientific, USA). The same procedure was followed for all replicates of each experimental condition.

\section{Statistical analysis}

All experiments were repeated at least four times, with four replicate wells of each condition tested for each repeat. Two-way ANOVA was performed, followed by a Tukey-Kramer posthoc test. All statistical tests were performed in GraphPad®, V6 (GraphPad Software Inc., La 
Jolla, CA, USA).

\section{Results}

\section{Effects of CSE}

Cigarette smoke extract (CSE) was obtained using established techniques, the experimental methodology of which has been shown to provide useful similarities to the in vivo situation (Bernhard et al. 2004). The cells were exposed to this CSE in order to validate our methods. Figure 2 represents the cell viability of three epithelial cell lines (IB3-1, C38 and BEAS-2B) and one macrophage cell line (J774) after 24 hours exposure to different concentrations of CSE. The results show that there was a dose-dependent decrease in cell viability such that viability was significantly less than control for all cell types and for all concentrations of CSE tested. Cytotoxicity, defined when viability was below $70 \%$ of the control, according to the ISO standard UNI EN ISO 10993-5, occurred in the C38 cell line at all concentrations of the CSE (Figure 2B), and at concentrations of 25\% and higher for the other cell types tested.

\section{Effects of EVE}

In order to ascertain the effects of the basic constituents within ECs, the vehicle with which the EC nicotine and flavours are delivered was investigated. The combination of propylene glycol (PG) and glycerine (G) was investigated at several ratios. Extracts from these ratios was added to BEAS-2B under submerged culture. The results are shown in figure 3 with the control value being that of cells with medium only added i.e. no EVE. The viability of cells was not linearly related to the ratio of PG:G. 


\section{Effects of ECE}

Several brands of ECs were purchased and the ECE was obtained as described. Cells were exposed to $1 \mathrm{~mL}$ of ECE for 24 hours, viability was measured and cytotoxicity was defined as above. When the cells were exposed to ECE from different brands, there was a decrease in the cell viability compared to the control, but this differed for different brands and different cell types. All data from the four main cell lines used are shown in Table 2.

\section{The effect of differing nicotine content within the same brand}

In order to assess the effects of EC nicotine concentration on cell viability, results were compared across three epithelial cell lines (IB3-1, C38 and BEAS-2B) and two macrophage cell lines (J774 and THP-1) following 24 hours exposure to Brand D ECE. This brand contains EC with nicotine concentrations of 6,12 and $18 \mathrm{mg}$ stated as on the packaging, and in each case, the flavouring is labelled as 'Tobacco'. The results (figure 4) show that there were significant decreases in the viability compared to the control, and this was true for all five cell lines. However, there is not a concentration-dependent relationship between increasing nicotine content and decreasing cell viability, suggesting that the drop in viability was not simply due to nicotine content. None of the ECE tested here were cytotoxic (i.e. resulted in cell viability $<70 \%$ control).

\section{The effect of different flavourings within the same brand}

Four different flavours from EC Brand E were used to study the effects of EC flavourings upon cell viability. Results, as shown in figure 5, indicate that some flavourings result in 
cytotoxicity but others do not, within the same brand, and at the same nicotine concentration. When cells were exposed to $100 \%$ strawberry flavoured ECE, cytotoxicity was demonstrated for cell types C38, BEAS-2B, IB3-1 and ranged from $66.9 \pm 2.8 \%$ control (IB3-1 cells) to 43.6 $\pm 3.6 \%$ control (BEAS-2B cells). Strawberry flavoured ECE proved cytotoxic to both the C38 and the BEAS-2B cell lines at all concentrations (figure 5B and 5C for C-38 and BEAS$2 \mathrm{~B}$ respectively). Cherry flavoured ECE was similarly damaging to the $\mathrm{C} 38$ and BEAS-2B cell lines, with cytotoxicity displayed at dilutions of $25 \%$ and higher and, in the case of BEAS-2B, tobacco flavoured ECE also proved cytotoxic at all dilutions tested. In addition, CALU-3 cells were exposed to the same flavoured ECEs as shown in Figure 5 at $100 \%$ dilution only. For this cell line, there was no significant difference between the viability of the exposed cells compared to the control for any of the flavours tested.

Two-way ANOVA was also performed in order to analyse the difference between the effects of different flavours. Since strawberry was found to demonstrate the most cytotoxicity, the effect of other flavours were compared to that of strawberry across all concentrations. The effect of strawberry flavour on the BEAS-2B cell line was statistically significantly different from the effect of apple, cherry and tobacco at all concentrations i.e. strawberry flavouring was more cytotoxic (statistically) than the other flavourings at all concentrations tested. In IB3-1, C38 and J774, at 100\% ECE concentration, the effect of strawberry flavour was statistically significantly different compared to other flavours. At other ECE concentrations, this varied. The results of this statistical analysis can be seen in Table 3.

The Strawberry flavour proved most cytotoxic of all the flavours tested and so this EC was again tested using two additional cell lines; THP-1 and Wi-38. The results showed no 
relationship between ECE concentration and cell viability and there was no cytotoxicity demonstrated at any concentration on either cell line, with cell viability reaching minimum levels of $83 \%$ and $104 \%$ of controls, for THP-1 and Wi-38 respectively, across the varying concentrations of ECE.

\section{The effect of the same flavouring within different brands}

All results are shown in Figure 6. Of the cell lines tested under these conditions, BEAS-2B were the most sensitive cell type, with viability falling to $22.4 \pm 3.7 \%$ of control after exposure to $100 \%$ ECE Brand $\mathrm{C}$, and $48.8 \pm 5.3 \%$ of control following exposure to $100 \%$ Brand $\mathrm{E}$. The other cell lines showed varying results, with cytotoxicity observed for some cell types with some brands, but this was not consistent across either different cell types or different brands. Brand B was cytotoxic only to IB3-1 cells at 100\% ECE, whilst Brand D did not induce any cytotoxicity in any of the cell lines tested.

\section{Discussion}

The current study aimed to analyse the effects of CSE and ECE on four cell lines; namely, three human bronchial epithelial cell lines (BEAS-2B, IB3-1 and C-38), and one macrophage cell line (J774). Using these four different cell lines allowed comparison of the potentially damaging effects of CSE and ECE. Further studies were then performed using additional cell types, fibroblasts (Wi-38), epithelials (CALU-3) and monocytes (THP-1) based on the results. This is the first study on the influence of CSE and ECE on cytotoxicity for these cell types. 
Using smoke or vapour extract on submerged cells to examine viability and cytotoxicity is an established methodology. Whilst not as physiologically relevant as work involving models at the air-liquid-interface (ALI) such as the study by Neilson et al (2015), the methodology used has allowed us to test a large range of brands and flavours; fifteen in total, at four concentrations, across four cell lines, performed in quadruplicate. A number of these tests were then repeated using the additional cell lines; THP-1, Wi38 and CALU-3. This has allowed us to determine which ECs have the most potential to cause cytotoxicity under these conditions. The limitations of this methodology are that the inhalation pattern of ECs may not be comparable to that of cigarettes (Farsalinos, Romagna, Tsiapras, et al. 2013), though there is currently no standard for ECs, and that the extract will deliver the water soluble components of the EC only. These ECs should also be used in future experiments on more physiological models such as co-cultures at the ALI where the EC vapour is delivered directly to the cell culture.

\section{CSE has a detrimental effect on cell viability}

All four concentrations of CSE tested resulted in a statistically significant difference in viability as compared to the control and to each other, in agreement with other studies. This result provides partial validation of our methodologies.

The use of CSE to investigate the effects of cigarettes on cultured cells has been extensively shown previously (Bernhard, Huck, Jakschitz, Pfister, Henderson, Bonn and Wick 2004, Carp and Janoff 1978). The results from our study are in accordance with a number of past studies on the toxicity of CSE which show reduction in cell viability even at low concentrations. Yoon et al. (2011) showed that there was a significant decrease in the cell viability of human bronchial smooth muscle cells (from cell lines) with increasing 
concentrations of CSE up to $30 \%$ concentration. In a study with alveolar type II cells, CSE, at $5 \%$ concentration, caused a reduction in viability, down to $19 \%$ of the control after 72 hours (Hoshino et al. 2001). There are as yet no standard techniques for generating ECE or for exposing cells to ECE, therefore, the data from figure 2 presented here provide confidence in these models, in the methodology for the generation of extract (EC or cigarette) and therefore in our ability to use data from these model in the analysis of the effects of ECE.

\section{The effect of the E-vehicle}

Extract was obtained using an EC which contained the E-vehicle only. This EVE was obtained with varying ratios of PG:G (figure 3). No concentration-dependent relationship was found between increasing ratios of PG:G and cell viability. Some statistically significant decreases in cell viability were found, though with a wide variability in data. Scheffler et al. (2015) investigated the effects of pure PG and G vapour on cultured primary bronchial cells at air liquid interface. The results showed a decrease in cell viability compared to the cells exposed to air only. However, there is little in the literature which assesses the effects of the extracts from PG and G, or indeed the combination of the two as seen in ECs.

\section{The effect of nicotine concentration}

Our results are consistent with previous work performed on EC cytotoxicity. Farsalinos et al. (2013) concluded that nicotine concentration had no effect on myocardial cell survival when comparing different ECEs, and Bahl et al. (2012) reported that cells did not survive better in samples without nicotine when subjected to direct e-liquid exposure. Cervellati (2014) however, showed that nicotine did have an effect on the viability and inflammatory response of cells exposed to EC vapour, though this was not using ECE. 
The mechanisms of actions of nicotine in terms of protection versus cytotoxicity are not clearly understood. Nevertheless, it is interesting to note that previous works on nicotine have focused on its anti-apoptotic properties (Argentin and Cicchetti 2004, Argentin and Cicchetti 2006, Laytragoon-Lewin et al. 2011). Hence, though the mechanism by which the cells are not damaged by increasing nicotine doses in ECE as seen here is unclear, the fact that nicotine does not have any major influence on the cell viability is well established, and our own findings support this.

\section{Relationship between EC flavourings and cell viability}

As shown in figure 5, the different flavourings tested caused a varied outcome in cell viability across the four cell lines, with BEAS-2B appearing the most susceptible, whereas CALU-3 showed no cytotoxic response to any of the four flavours tested.

Although the flavourings used in E-liquid fabrication are often common food additives, the effects of these additives once heated and aerosolised, in conjunction with the other constituents is still largely unknown. Additional variability may come from the type and amount of flavourings included in the EC which vary between manufacturers, with the potential to affect the cytotoxicity. Moreover, even the method of production of natural flavourings such as 'tobacco' or 'coffee' and 'cinnamon' are different among the various manufacturers. Bahl et al. (2012) showed that the cytotoxic effect of ECs on human pulmonary fibroblasts was due to the concentration of chemicals used to produce different flavours. The concentration of these chemicals varied even between flavoured liquids purchased from the same manufacturer. ECs with various flavours have been shown to result in particular effects on in vitro cell lines, and cinnamon flavourings have been particularly 
noted in the literature (Bahl, Lin, Xu, Davis, Wang and Talbot 2012, Behar, Davis, Wang, Bahl, Lin and Talbot 2014, Lerner et al. 2015).

The constituents of ECs cannot be assumed to be completely non-toxic or safe. For example, the presence of formaldehyde-releasing agents has been found in EC vapour (Jensen et al. 2015) and the main ingredient of cinnamon flavour, cinnamaldehyde, is converted to benzaldehyde at high temperatures (Friedman et al. 2000)Our own results support that the flavourings used in ECs affect the potential cytotoxicity of the EC vapour.

\section{Relationship between the same flavour, different brands with cell viability}

Analysis of the different flavoured ECE indicated that there are significant differences in the cytotoxic effects within one brand, and thus there is a concern that flavour choice may influence the health effects of EC. We also wanted to examine the effects of one flavour (tobacco) across different brands (Brand B, C, D and E). These data indicate that there are significant differences in the contents of EC, despite similar packaging labelling (e.g. all brands tested here simply declared Tobacco Flavourings). This suggests that there is a requirement for more rigorous indication of content and further testing of the different EC products. If EC are to be used as a safe alternative to tobacco or nicotine replacement products for smoking cessation (ASH 2015), then the consumer needs to know the precise contents, and the smoking cessation clinics and advisors need to know the likely health effects, since our data indicate that not all EC are the same.

\section{The effect of different cell types}

In this study we employed a total of seven different cell types for various experiments. Four 
of these were bronchial epithelial cell lines, two were macrophages and one was a fibroblast cell line. There is differential susceptibility to ECE for different cell types and this may be related to the cell type, the ECE or a combination of the two.

There was a difference between the epithelial to the fibroblasts, the epithelial to the macrophages and the fibroblasts to the macrophages. However, this was not clear, with differences in response between different epithelial cell lines and different macrophage cell lines. The BEAS-2B cell line appeared to be the most sensitive of all the cells tested in this study.

PMA treated THP-1 cells have been previously found to have a resistance to apoptotic stimuli which is comparable to primary human macrophage cell lines (Daigneault et al. 2010). These were less susceptible to cytotoxicity in our experiments than the mouse macrophage J774.

These data indicate that the cell line chosen to explore the cytotoxicity of ECs can influence the findings of studies in EC safety and toxicity testing. Thus there is still a need to standardise a testing protocol for an in vitro model of human airways with which to examine the potential health effects of ECE.

\section{Conclusions}

The aim of this study was to investigate the effects on viability of a variety of ECEs from different brands and with varying nicotine concentrations and flavourings. This was performed using four cell lines of relevance to the airways, namely bronchial epithelial cells 
and macrophages, followed by further testing with additional epithelial, macrophage and fibroblast cell lines. A number of conclusions can be drawn from the results of this study.

CSE has a dose-dependent detrimental impact on the cell viability across all four cell types tested. This was a good validation of the methodology employed in this study and sits well with the current and extensive literature.

Nicotine concentration in ECs has little or no dose-dependent influence on the cell viability across all cell types. This again, appears to agree with the majority of the literature though this is a subject which is not fully explained in the current knowledge.

The contents of different brands of EC and of different types within the same brand are very poorly defined. This is a concern since we show that EC flavourings can cause a significant decrease in cell viability, with fruit flavours especially resulting in greater cytotoxicity. We also show that cytotoxicity varies widely across brands, with identical descriptions of products, including flavour, resulting in significantly different effects on cell viability.

And finally, the choice of cell line employed in the testing of ECs can result in significant differences in the outcome of the study. More work needs to be done to identify why this is the case.

This study has allowed us to identify the cytotoxic effects of different brands and flavours of ECs using extracts in submerged cell culture. The next phase is to take the most cytotoxic ECs forward for testing on cultures at ALI. 


\section{Funding}

This work was supported by the School of Engineering and Applied Science, Aston

University (UK). No external funding was received for this project.

\section{Disclosure of Interest}

The authors report no conflicts of interest.

\section{Acknowledgements}

We gratefully acknowledge the input of Dr Sarah Lee (School of Engineering and Applied Science, Aston University) in preparation of the manuscript.

\section{References}

Argentin G, Cicchetti R. 2004. Genotoxic and antiapoptotic effect of nicotine on human gingival fibroblasts. Toxicological sciences : an official journal of the Society of Toxicology. May;79:75-81.

Argentin G, Cicchetti R. 2006. Evidence for the role of nitric oxide in antiapoptotic and genotoxic effect of nicotine on human gingival fibroblasts. Apoptosis : an international journal on programmed cell death. Nov;11:1887-1897.

Use of electronic cigarettes (vapourisers) among adults in Great Britain: action on smoking and health. Available from http://www.ash.org.uk/files/documents/ASH_891.pdf

Bahl V, Lin S, Xu N, Davis B, Wang Y-h, Talbot P. 2012. Comparison of electronic cigarette refill fluid cytotoxicity using embryonic and adult models. Reprod Toxicol. 12//;34:529-537.

Behar RZ, Davis B, Wang Y, Bahl V, Lin S, Talbot P. 2014. Identification of toxicants in cinnamon-flavored electronic cigarette refill fluids. Toxicology in Vitro. 3//;28:198-208.

Bernhard D, Huck CW, Jakschitz T, Pfister G, Henderson B, Bonn GK, Wick G. 2004. Development and evaluation of an in vitro model for the analysis of cigarette smoke effects on cultured cells and tissues. J Pharmacol Toxicol Methods. Jul-Aug;50:45-51. Epub 2004/07/06. 
Breland AB, Spindle T, Weaver M, Eissenberg T. 2014. Science and electronic cigarettes: current data, future needs. Journal of addiction medicine.8:223-233.

Britton J, Bogdanovica I. 2014. Electronic Cigarettes, A report commissioned by Public Health England. PH England.

Cameron JM, Howell DN, White JR, Andrenyak DM, Layton ME, Roll JM. 2014. Variable and potentially fatal amounts of nicotine in e-cigarette nicotine solutions. Tobacco control. Jan;23:77-78.

Carp H, Janoff A. 1978. Possible mechanisms of emphysema in smokers. In vitro suppression of serum elastase-inhibitory capacity by fresh cigarette smoke and its prevention by antioxidants. The American review of respiratory disease. Sep;118:617-621.

Cervellati F, Muresan X, Sticozzi C, Gambari R, Montagner G, Forman H, Torricelli C, Maioli E, Valacchi G. 2014. Comparative effects between electronic and cigarette smoke in human keratinocytes and epithelial lung cells. Toxicology in Vitro.28:999-1005.

Daigneault M, Preston JA, Marriott HM, Whyte MKB, Dockrell DH. 2010. The Identification of Markers of Macrophage Differentiation in PMA-Stimulated THP-1 Cells and Monocyte-Derived Macrophages. Plos One.5:e8668.

Farsalinos K, Romagna G, Tsiapras D, Kyrzopoulos S, Voudris V. 2013. Evaluation of Electronic Cigarette Use (Vaping) Topography and Estimation of Liquid Consumption: Implications for Research Protocol Standards Definition and for Public Health Authorities' Regulation. International journal of environmental research and public health.10:2500.

Farsalinos KE, Romagna G, Allifranchini E, Ripamonti E, Bocchietto E, Todeschi S, Tsiapras D, Kyrzopoulos S, Voudris V. 2013. Comparison of the cytotoxic potential of cigarette smoke and electronic cigarette vapour extract on cultured myocardial cells. International journal of environmental research and public health. Oct;10:5146-5162.

Summary of Results: Laboratory Analysis of Electronic Cigarettes Conducted By FDA. 22/04/2014: U.S. Food and Drug Administration. Available from http://www.fda.gov/NewsEvents/PublicHealthFocus/ucm173146.htm

Friedman M, Kozukue N, Harden LA. 2000. Cinnamaldehyde content in foods determined by gas chromatography-mass spectrometry. Journal of Agricultural and Food Chemistry.48:5702-5709.

Goniewicz ML, Knysak J, Gawron M, Kosmider L, Sobczak A, Kurek J, Prokopowicz A, Jablonska-Czapla M, Rosik-Dulewska C, Havel C. 2014. Levels of selected carcinogens and toxicants in vapour from electronic cigarettes. Tobacco control.23:133-139.

Hoshino Y, Mio T, Nagai S, Miki H, Ito I, Izumi T. 2001. Cytotoxic effects of cigarette smoke extract on an alveolar type II cell-derived cell line. American Journal of Physiology Lung Cellular and Molecular Physiology. 2001-08-01 00:00:00;281:L509-L516.

ISO. 1991. ISO 3308: Routine analytical cigarette-smoking machine - Definitions and standard conditions. In: International Organization for Standardization.

Jensen RP, Luo W, Pankow JF, Strongin RM, Peyton DH. 2015. Hidden Formaldehyde in ECigarette Aerosols. New England Journal of Medicine.372:392-394.

Laytragoon-Lewin N, Bahram F, Rutqvist LE, Turesson I, Lewin F. 2011. Direct effects of pure nicotine, cigarette smoke extract, Swedish-type smokeless tobacco (Snus) extract and ethanol on human normal endothelial cells and fibroblasts. Anticancer research. May;31:1527-1534. 
Lerner CA, Sundar IK, Yao H, Gerloff J, Ossip DJ, McIntosh S, Robinson R, Rahman I. 2015. Vapors produced by electronic cigarettes and e-juices with flavorings induce toxicity, oxidative stress, and inflammatory response in lung epithelial cells and in mouse lung. Plos One.10:e0116732.

Misra M, Leverette RD, Cooper BT, Bennett MB, Brown SE. 2014. Comparative in vitro toxicity profile of electronic and tobacco cigarettes, smokeless tobacco and nicotine replacement therapy products: e-liquids, extracts and collected aerosols. International journal of environmental research and public health.11:11325-11347.

Neilson L, Mankus C, Thorne D, Jackson G, DeBay J, Meredith C. 2015. Development of an in vitro cytotoxicity model for aerosol exposure using 3D reconstructed human airway tissue; application for assessment of e-cigarette aerosol. Toxicology in Vitro.29:1952-1962.

Orr MS. 2014. Electronic cigarettes in the USA: a summary of available toxicology data and suggestions for the future. Tobacco Control. May 1, 2014;23:ii18-ii22.

Regan AK, Promoff G, Dube SR, Arrazola R. 2013. Electronic nicotine delivery systems: adult use and awareness of the 'e-cigarette' in the USA. Tobacco control.22:19-23.

Romagna G, Allifranchini E, Bocchietto E, Todeschi S, Esposito M, Farsalinos KE. 2013. Cytotoxicity evaluation of electronic cigarette vapor extract on cultured mammalian fibroblasts (ClearStream-LIFE): comparison with tobacco cigarette smoke extract. Inhalation Toxicology.25:354-361.

Scheffler S, Dieken H, Krischenowski O, Förster C, Branscheid D, Aufderheide M. 2015. Evaluation of E-Cigarette Liquid Vapor and Mainstream Cigarette Smoke after Direct Exposure of Primary Human Bronchial Epithelial Cells. International journal of environmental research and public health.12:3915-3925.

Thomas L, Bielemeier A, Lambert PA, Darveau RP, Marshall LJ, Devitt A. 2013. The NTerminus of CD14 Acts to Bind Apoptotic Cells and Confers Rapid-Tethering Capabilities on Non-Myeloid Cells. Plos One.8:e70691.

Yoon CH, Park H-J, Cho Y-W, Kim E-J, Lee JD, Kang KR, Han J, Kang D. 2011. Cigarette Smoke Extract-induced Reduction in Migration and Contraction in Normal Human Bronchial Smooth Muscle Cells. The Korean Journal of Physiology \& Pharmacology : Official Journal of the Korean Physiological Society and the Korean Society of Pharmacology. 12/27

10/19/received

11/21/revised

12/01/accepted;15:397-403. 
Table 1. Manufacturer's information provided on the packaging of the cigarettes and five different EC brands (anonymised as A to E) used in the current study.

\begin{tabular}{|c|c|c|c|}
\hline Sample (type) & Flavour & $\begin{array}{l}\text { Nicotine } \\
\text { content }\end{array}$ & Other additives / Information on packaging \\
\hline Cigarette & N/A & $0.8 \mathrm{mg}$ & $10 \mathrm{mg}$ tar; $10 \mathrm{mg}$ carbon monoxide \\
\hline $\begin{array}{l}\mathrm{A} \\
(\mathrm{EC})\end{array}$ & N/A & $2.4 \% / \mathrm{mL}$ & Water, polyethylene glycol, glycerine \& flavours \\
\hline & Dark Cherry & $\begin{array}{l}12.5 \mathrm{mg} \\
3.5 \% \mathrm{v} / \mathrm{v}\end{array}$ & Dark cherry regular flavour \\
\hline $\begin{array}{c}\mathrm{B} \\
\text { (EC) }\end{array}$ & Tobacco & $\begin{array}{l}12.5 \mathrm{mg} \\
3.5 \% \mathrm{v} / \mathrm{v}\end{array}$ & Tobacco flavour \\
\hline & Crisp Mint & $\begin{array}{l}12.5 \mathrm{mg} \\
3.5 \% \mathrm{v} / \mathrm{v}\end{array}$ & Crisp mint flavour regular \\
\hline $\mathrm{C}$ & Tobacco & $1.8 \%$ & Propylene glycol, traces of nuts \\
\hline (EC) & Menthol & $1.8 \%$ & Propylene glycol, traces of nuts \\
\hline \multirow{3}{*}{$\begin{array}{l}\mathrm{D} \\
(\mathrm{EC})\end{array}$} & Tobacco & $\begin{array}{l}6 \mathrm{mg} \\
0.6 \%\end{array}$ & Classic Tobacco flavour, propylene glycol \\
\hline & Tobacco & $\begin{array}{l}12 \mathrm{mg} \\
1.2 \%\end{array}$ & Classic Tobacco flavour, propylene glycol \\
\hline & Tobacco & $\begin{array}{l}18 \mathrm{mg} \\
1.8 \%\end{array}$ & Classic Tobacco flavour, propylene glycol \\
\hline \multirow{3}{*}{$\begin{array}{c}\mathrm{E} \\
(\mathrm{EC})\end{array}$} & Apple & $\begin{array}{c}16 \mathrm{mg} \\
1.6 \% / \mathrm{mL}\end{array}$ & $\begin{array}{l}\text { Water, propylene glycol, glycerine and flavours. } \\
\text { Traces of nuts }\end{array}$ \\
\hline & Coffee & $\begin{array}{c}16 \mathrm{mg} \\
1.6 \% / \mathrm{mL}\end{array}$ & $\begin{array}{l}\text { Water, propylene glycol, glycerine and flavours. } \\
\text { Traces of nuts }\end{array}$ \\
\hline & Vanilla & $\begin{array}{c}16 \mathrm{mg} \\
1.6 \% / \mathrm{mL}\end{array}$ & $\begin{array}{l}\text { Water, propylene glycol, glycerine and flavours. } \\
\text { Traces of nuts }\end{array}$ \\
\hline
\end{tabular}




\begin{tabular}{|crl|}
\hline Cherry & $16 \mathrm{mg}$ & Water, propylene glycol, glycerine and flavours. \\
& $1.6 \% / \mathrm{mL}$ & Traces of nuts \\
\hline Strawberry & $16 \mathrm{mg}$ & Water, propylene glycol, glycerine and flavours. \\
& $1.6 \% / \mathrm{mL}$ & Traces of nuts \\
\hline Tobacco & $16 \mathrm{mg}$ & Water, propylene glycol, glycerine and flavours. \\
& $1.6 \% / \mathrm{mL}$ & Traces of nuts \\
\hline
\end{tabular}


Table 2. Viability data as compared to control for the four main cell lines following exposure to varying concentrations (\%) of ECE. Mean values are shown with standard deviations in brackets. Shaded boxes show cytotoxicity, i.e. viability which fell below $70 \%$ of control.

\begin{tabular}{|c|c|c|c|c|c|c|c|c|c|c|c|c|c|c|c|c|c|c|}
\hline \multirow[b]{2}{*}{$\begin{array}{c}\text { Sample } \\
\text { (type) }\end{array}$} & \multirow[b]{2}{*}{ Flavour } & \multicolumn{2}{|l|}{ Cell line } & \multicolumn{2}{|c|}{ C38 } & \multirow[b]{2}{*}{100} & \multicolumn{4}{|c|}{ BEAS-2B } & \multicolumn{4}{|c|}{ IB3-1 } & \multicolumn{4}{|c|}{ J774 } \\
\hline & & $\begin{array}{l}\text { Nicotine } \\
\text { Content }\end{array}$ & 12.5 & 25 & 50 & & 12.5 & 25 & 50 & 100 & 12.5 & 25 & 50 & 100 & 12.5 & 25 & 50 & 100 \\
\hline A (EC) & - & $2.4 \% / \mathrm{mL}$ & $\begin{array}{l}95.5 \\
(5.9) \\
\end{array}$ & $\begin{array}{l}91.0 \\
(5.4) \\
\end{array}$ & $\begin{array}{l}90.6 \\
(4.7) \\
\end{array}$ & $\begin{array}{l}88.5 \\
(4.6) \\
\end{array}$ & $\begin{array}{l}89.6 \\
(7.5) \\
\end{array}$ & $\begin{array}{l}85.7 \\
(7.6) \\
\end{array}$ & $\begin{array}{l}85.4 \\
(7.6) \\
\end{array}$ & $\begin{array}{l}84.8 \\
(7.5) \\
\end{array}$ & $\begin{array}{l}89.7 \\
(4.2) \\
\end{array}$ & $\begin{array}{l}89.6 \\
(3.9) \\
\end{array}$ & \begin{tabular}{|l|}
88.5 \\
$(4.1)$ \\
\end{tabular} & $\begin{array}{l}79.2 \\
(3.7) \\
\end{array}$ & $\begin{array}{l}99.7 \\
(4.5) \\
\end{array}$ & $\begin{array}{l}99.4 \\
(5.9) \\
\end{array}$ & $\begin{array}{l}98.9 \\
(2.7) \\
\end{array}$ & $\begin{array}{l}77.9 \\
(3.5) \\
\end{array}$ \\
\hline \multirow{3}{*}{ B (EC) } & Dark Cherry & $\begin{array}{c}12.5 \mathrm{mg} \\
3.5 \% \mathrm{v} / \mathrm{v} \\
\end{array}$ & $\begin{array}{l}98.6 \\
(5.4) \\
\end{array}$ & $\begin{array}{l}93.9 \\
(5.4) \\
\end{array}$ & $\begin{array}{l}89.2 \\
(3.7) \\
\end{array}$ & $\begin{array}{l}89.5 \\
(4.4) \\
\end{array}$ & $\begin{array}{l}94.3 \\
(7.3) \\
\end{array}$ & $\begin{array}{l}92.1 \\
(7.6) \\
\end{array}$ & $\begin{array}{l}86.1 \\
(7.2) \\
\end{array}$ & $\begin{array}{l}81.5 \\
(7.6) \\
\end{array}$ & $\begin{array}{l}90.6 \\
(7.1) \\
\end{array}$ & $\begin{array}{l}90.9 \\
(7.0) \\
\end{array}$ & $\begin{array}{l}92.3 \\
(6.5) \\
\end{array}$ & $\begin{array}{l}83.6 \\
(6.3) \\
\end{array}$ & $\begin{array}{l}97.6 \\
(3.6) \\
\end{array}$ & $\begin{array}{l}97.2 \\
(4.7) \\
\end{array}$ & $\begin{array}{l}96.9 \\
(2.9) \\
\end{array}$ & $\begin{array}{l}88.7 \\
(2.9) \\
\end{array}$ \\
\hline & Tobacco & $\begin{array}{c}12.5 \mathrm{mg} \\
3.5 \% \mathrm{v} / \mathrm{v}\end{array}$ & $\begin{array}{l}80.9 \\
(5.0) \\
\end{array}$ & $\begin{array}{l}80.6 \\
(8.7) \\
\end{array}$ & $\begin{array}{l}79.8 \\
(8.6) \\
\end{array}$ & $\begin{array}{l}77.3 \\
(7.3) \\
\end{array}$ & $\begin{array}{l}91.8 \\
(9.3) \\
\end{array}$ & $\begin{array}{l}92.2 \\
(9.8) \\
\end{array}$ & $\begin{array}{l}88.1 \\
(7.6) \\
\end{array}$ & $\begin{array}{l}88.1 \\
(9.6) \\
\end{array}$ & $\begin{array}{l}88.6 \\
(4.3) \\
\end{array}$ & $\begin{array}{l}88.4 \\
(4.1) \\
\end{array}$ & $\begin{array}{l}78.4 \\
(4.0) \\
\end{array}$ & $\begin{array}{l}58.4 \\
(3.9) \\
\end{array}$ & $\begin{array}{l}102.0 \\
(4.4)\end{array}$ & $\begin{array}{l}90.6 \\
(4.4) \\
\end{array}$ & $\begin{array}{l}88.5 \\
(4.6) \\
\end{array}$ & $\begin{array}{l}68.2 \\
(5.6) \\
\end{array}$ \\
\hline & Crisp Mint & $\begin{array}{c}12.5 \mathrm{mg} \\
3.5 \% \mathrm{v} / \mathrm{v} \\
\end{array}$ & $\begin{array}{l}95.5 \\
(3.6) \\
\end{array}$ & $\begin{array}{l}94.6 \\
(5.7) \\
\end{array}$ & $\begin{array}{l}93.1 \\
(3.7) \\
\end{array}$ & $\begin{array}{l}93.1 \\
(4.7) \\
\end{array}$ & $\begin{array}{l}92.3 \\
(4.2) \\
\end{array}$ & $\begin{array}{l}90.8 \\
(4.1) \\
\end{array}$ & $\begin{array}{l}89.9 \\
(4.6) \\
\end{array}$ & $\begin{array}{l}82.3 \\
(2.7) \\
\end{array}$ & $\begin{array}{l}88.3 \\
(4.0) \\
\end{array}$ & $\begin{array}{l}87.4 \\
(4.2) \\
\end{array}$ & $\begin{array}{l}89.3 \\
(3.7) \\
\end{array}$ & $\begin{array}{l}79.1 \\
(4.4) \\
\end{array}$ & $\begin{array}{l}89.6 \\
(4.2) \\
\end{array}$ & $\begin{array}{l}91.2 \\
(5.1) \\
\end{array}$ & $\begin{array}{l}90.1 \\
(5.8) \\
\end{array}$ & $\begin{array}{l}80.2 \\
(4.8) \\
\end{array}$ \\
\hline \multirow{2}{*}{ C (EC) } & Tobacco & $1.8 \%$ & $\begin{array}{l}90.3 \\
(5.2)\end{array}$ & $\begin{array}{l}92.3 \\
(6.7)\end{array}$ & $\begin{array}{l}83.4 \\
(6.9)\end{array}$ & $\begin{array}{l}72.9 \\
(6.4)\end{array}$ & $\begin{array}{l}92.1 \\
(5.5)\end{array}$ & $\begin{array}{l}85.1 \\
(5.8)\end{array}$ & $\begin{array}{l}54.8 \\
(8.9)\end{array}$ & $\begin{array}{l}22.4 \\
(3.7) \\
\end{array}$ & $\begin{array}{l}88.5 \\
(4.8)\end{array}$ & $\begin{array}{l}89.1 \\
(4.1)\end{array}$ & $\begin{array}{l}89.7 \\
(3.4)\end{array}$ & $\begin{array}{l}78.0 \\
(4.2)\end{array}$ & $\begin{array}{l}90.0 \\
(3.8)\end{array}$ & $\begin{array}{l}89.9 \\
(4.0)\end{array}$ & $\begin{array}{l}89.4 \\
(4.1)\end{array}$ & $\begin{array}{l}91.2 \\
(3.8) \\
\end{array}$ \\
\hline & Menthol & $1.8 \%$ & \begin{tabular}{|l|}
89.4 \\
$(8.9)$ \\
\end{tabular} & $\begin{array}{l}89.8 \\
(6.9) \\
\end{array}$ & $\begin{array}{l}87.9 \\
(7.5) \\
\end{array}$ & $\begin{array}{l}83.2 \\
(5.4) \\
\end{array}$ & $\begin{array}{l}89.6 \\
(5.7) \\
\end{array}$ & \begin{tabular}{|l|}
89.3 \\
$(5.1)$ \\
\end{tabular} & $\begin{array}{l}87.7 \\
(6.2) \\
\end{array}$ & $\begin{array}{l}83.9 \\
(5.5) \\
\end{array}$ & $\begin{array}{l}89.5 \\
(3.8) \\
\end{array}$ & $\begin{array}{l}87.1 \\
(9.9) \\
\end{array}$ & $\begin{array}{l}88.2 \\
(2.6) \\
\end{array}$ & \begin{tabular}{|l|}
89.5 \\
$(3.0)$ \\
\end{tabular} & $\begin{array}{l}91.4 \\
(4.4) \\
\end{array}$ & $\begin{array}{l}90.2 \\
(4.2) \\
\end{array}$ & $\begin{array}{l}88.7 \\
(3.9) \\
\end{array}$ & $\begin{array}{l}89.1 \\
(5.3) \\
\end{array}$ \\
\hline \multirow{3}{*}{ D (EC) } & Tobacco & $\begin{array}{l}6 \mathrm{mg} \\
0.6 \%\end{array}$ & $\begin{array}{l}88.8 \\
(5.2)\end{array}$ & $\begin{array}{l}84.6 \\
(5.3)\end{array}$ & $\begin{array}{l}84.9 \\
(4.4)\end{array}$ & $\begin{array}{l}79.9 \\
(4.1)\end{array}$ & $\begin{array}{l}85.6 \\
(5.9)\end{array}$ & $\begin{array}{l}76.4 \\
(5.7)\end{array}$ & $\begin{array}{l}75.6 \\
(6.9)\end{array}$ & $\begin{array}{l}73.1 \\
(4.3)\end{array}$ & $\begin{array}{l}87.0 \\
(3.8)\end{array}$ & $\begin{array}{l}86.1 \\
(2.9)\end{array}$ & $\begin{array}{l}86.1 \\
(4.1)\end{array}$ & $\begin{array}{l}76.4 \\
(3.8)\end{array}$ & $\begin{array}{l}89.4 \\
(3.1)\end{array}$ & $\begin{array}{l}89.1 \\
(3.7)\end{array}$ & $\begin{array}{l}89.1 \\
(4.4)\end{array}$ & $\begin{array}{l}89.4 \\
(3.9)\end{array}$ \\
\hline & Tobacco & $\begin{array}{l}12 \mathrm{mg} \\
1.2 \%\end{array}$ & $\begin{array}{l}94.1 \\
(5.1) \\
\end{array}$ & $\begin{array}{l}90.9 \\
(5.3) \\
\end{array}$ & \begin{tabular}{|l|}
88.9 \\
$(4.6)$ \\
\end{tabular} & $\begin{array}{l}84.2 \\
(6.8) \\
\end{array}$ & $\begin{array}{l}99.4 \\
(7.4) \\
\end{array}$ & $\begin{array}{l}96.2 \\
(7.7) \\
\end{array}$ & $\begin{array}{l}93.1 \\
(7.3) \\
\end{array}$ & $\begin{array}{c}84.7(6 \\
.7) \\
\end{array}$ & $\begin{array}{l}98.4 \\
(4.7) \\
\end{array}$ & $\begin{array}{l}99.3 \\
(3.9) \\
\end{array}$ & $\begin{array}{l}99.9 \\
(3.4) \\
\end{array}$ & $\begin{array}{l}88.8 \\
(3.0) \\
\end{array}$ & $\begin{array}{l}99.7 \\
(2.8) \\
\end{array}$ & $\begin{array}{l}98.3 \\
(5.3) \\
\end{array}$ & $\begin{array}{l}98.2 \\
(3.6) \\
\end{array}$ & $\begin{array}{l}88.2 \\
(2.5) \\
\end{array}$ \\
\hline & Tobacco & $\begin{array}{l}18 \mathrm{mg} \\
1.8 \% \\
\end{array}$ & $\begin{array}{l}93.3 \\
(5.6) \\
\end{array}$ & $\begin{array}{l}86.4 \\
(5.7) \\
\end{array}$ & $\begin{array}{l}85.2 \\
(5.1) \\
\end{array}$ & $\begin{array}{l}84.6 \\
(5.1) \\
\end{array}$ & $\begin{array}{l}95.7 \\
(2.9) \\
\end{array}$ & $\begin{array}{l}90.3 \\
(4.2) \\
\end{array}$ & $\begin{array}{l}89.3 \\
(3.7) \\
\end{array}$ & $\begin{array}{l}88.6 \\
(4.2) \\
\end{array}$ & $\begin{array}{l}89.7 \\
(3.7) \\
\end{array}$ & $\begin{array}{l}89.2 \\
(3.8) \\
\end{array}$ & $\begin{array}{l}91.1 \\
(3.3) \\
\end{array}$ & $\begin{array}{l}77.9 \\
(3.0) \\
\end{array}$ & $\begin{array}{l}89.5 \\
(2.9) \\
\end{array}$ & $\begin{array}{l}89.8 \\
(4.4) \\
\end{array}$ & $\begin{array}{l}91.1 \\
(4.3)\end{array}$ & $\begin{array}{l}77.1 \\
(6.3) \\
\end{array}$ \\
\hline \multirow{6}{*}{$\mathbf{E}(\mathbf{E C})$} & Apple & $\begin{array}{c}16 \mathrm{mg} \\
1.6 \% / \mathrm{mL}\end{array}$ & $\begin{array}{l}87.4 \\
(4.5)\end{array}$ & $\begin{array}{l}81.9 \\
(4.6)\end{array}$ & $\begin{array}{r}78.2 \\
(4.6)\end{array}$ & $\begin{array}{l}74.4 \\
(5.6)\end{array}$ & $\begin{array}{l}95.5 \\
(7.4)\end{array}$ & $\begin{array}{l}92.4 \\
(5.6)\end{array}$ & $\begin{array}{l}90.2 \\
(8.6)\end{array}$ & $\begin{array}{l}83.8 \\
(7.6)\end{array}$ & $\begin{array}{l}86.0 \\
(3.5)\end{array}$ & $\begin{array}{l}84.7 \\
(2.9)\end{array}$ & $\begin{array}{l}79.5 \\
(2.9)\end{array}$ & $\begin{array}{l}75.8 \\
(3.0)\end{array}$ & $\begin{array}{l}87.6 \\
(3.0)\end{array}$ & $\begin{array}{l}87.6 \\
(3.6)\end{array}$ & $\begin{array}{l}85.1 \\
(3.2)\end{array}$ & $\begin{array}{l}76.6 \\
(2.8)\end{array}$ \\
\hline & Coffee & $\begin{array}{c}16 \mathrm{mg} \\
1.6 \% / \mathrm{mL}\end{array}$ & \begin{tabular}{|l|}
89.3 \\
$(5.4)$ \\
\end{tabular} & \begin{tabular}{|l|}
87.9 \\
$(4.8)$ \\
\end{tabular} & $\begin{array}{l}87.3 \\
(4.0) \\
\end{array}$ & $\begin{array}{l}86.7 \\
(4.1) \\
\end{array}$ & $\begin{array}{l}92.0 \\
(5.1) \\
\end{array}$ & $\begin{array}{l}91.5 \\
(5.5) \\
\end{array}$ & $\begin{array}{l}91.9 \\
(3.9) \\
\end{array}$ & $\begin{array}{l}87.1 \\
(3.7) \\
\end{array}$ & $\begin{array}{l}90.1 \\
(4.5)\end{array}$ & $\begin{array}{l}89.9 \\
(3.9) \\
\end{array}$ & $\begin{array}{l}89.4 \\
(4.1) \\
\end{array}$ & $\begin{array}{l}79.8 \\
(3.1) \\
\end{array}$ & $\begin{array}{l}93.1 \\
(4.3) \\
\end{array}$ & $\begin{array}{l}90.8 \\
(4.4) \\
\end{array}$ & $\begin{array}{l}90.9 \\
(3.8) \\
\end{array}$ & $\begin{array}{r}79.9 \\
(3.8) \\
\end{array}$ \\
\hline & Vanilla & $\begin{array}{c}16 \mathrm{mg} \\
1.6 \% / \mathrm{mL}\end{array}$ & $\begin{array}{l}87.9 \\
(6.9)\end{array}$ & $\begin{array}{l}82.8 \\
(6.1)\end{array}$ & $\begin{array}{l}82.2 \\
(4.4)\end{array}$ & $\begin{array}{l}79.4 \\
(5.1)\end{array}$ & $\begin{array}{l}93.2 \\
(3.9)\end{array}$ & $\begin{array}{l}89.3 \\
(3.8)\end{array}$ & $\begin{array}{l}88.4 \\
(4.1)\end{array}$ & $\begin{array}{l}85.6 \\
(5.4)\end{array}$ & $\begin{array}{l}90.8 \\
(3.6)\end{array}$ & $\begin{array}{l}90.5 \\
(4.1)\end{array}$ & $\begin{array}{l}89.8 \\
(4.4)\end{array}$ & $\begin{array}{l}78.8 \\
(3.4)\end{array}$ & $\begin{array}{l}90.5 \\
(4.9)\end{array}$ & $\begin{array}{l}89.0 \\
(3.9)\end{array}$ & $\begin{array}{l}88.5 \\
(6.1)\end{array}$ & $\begin{array}{l}79.6 \\
(3.1)\end{array}$ \\
\hline & Cherry & $\begin{array}{c}16 \mathrm{mg} \\
1.6 \% / \mathrm{mL}\end{array}$ & $\begin{array}{l}71.2 \\
(2.8) \\
\end{array}$ & $\begin{array}{l}66.5 \\
(3.5) \\
\end{array}$ & $\begin{array}{l}65.1 \\
(4.6) \\
\end{array}$ & $\begin{array}{l}64.9 \\
(3.6) \\
\end{array}$ & \begin{tabular}{|l}
74.0 \\
$(4.7)$ \\
\end{tabular} & $\begin{array}{l}60.6 \\
(4.1) \\
\end{array}$ & $\begin{array}{l}57.6 \\
(5.5) \\
\end{array}$ & $\begin{array}{l}53.7 \\
(4.2) \\
\end{array}$ & \begin{tabular}{|l|}
88.4 \\
$(4.2)$ \\
\end{tabular} & $\begin{array}{l}87.4 \\
(3.5) \\
\end{array}$ & $\begin{array}{l}88.0 \\
(4.4) \\
\end{array}$ & $\begin{array}{l}88.7 \\
(4.3) \\
\end{array}$ & $\begin{array}{l}90.0 \\
(4.0) \\
\end{array}$ & \begin{tabular}{|l|}
89.3 \\
$(4.3)$ \\
\end{tabular} & $\begin{array}{l}89.1 \\
(6.1) \\
\end{array}$ & $\begin{array}{l}89.8 \\
(3.5) \\
\end{array}$ \\
\hline & Strawberry & $\begin{array}{c}16 \mathrm{mg} \\
1.6 \% / \mathrm{mL}\end{array}$ & $\begin{array}{l}67.9 \\
(4.9) \\
\end{array}$ & $\begin{array}{l}63.3 \\
(4.2) \\
\end{array}$ & $\begin{array}{l}49.2 \\
(3.8) \\
\end{array}$ & $\begin{array}{l}47.5 \\
(4.7) \\
\end{array}$ & $\begin{array}{l}56.2 \\
(3.8) \\
\end{array}$ & $\begin{array}{l}46.3 \\
(3.7) \\
\end{array}$ & $\begin{array}{l}45.1 \\
(4.3) \\
\end{array}$ & $\begin{array}{l}43.6 \\
(3.6) \\
\end{array}$ & $\begin{array}{l}90.6 \\
(3.9) \\
\end{array}$ & $\begin{array}{l}87.5 \\
(3.3) \\
\end{array}$ & $\begin{array}{l}78.9 \\
(4.0) \\
\end{array}$ & $\begin{array}{l}66.9 \\
(2.8) \\
\end{array}$ & $\begin{array}{l}90.7 \\
(4.4) \\
\end{array}$ & $\begin{array}{l}88.3 \\
(3.2) \\
\end{array}$ & $\begin{array}{l}79.3 \\
(4.2) \\
\end{array}$ & $\begin{array}{l}68.9 \\
(4.0) \\
\end{array}$ \\
\hline & Tobacco & $\begin{array}{c}16 \mathrm{mg} \\
1.6 \% / \mathrm{mL}\end{array}$ & $\begin{array}{l}89.1 \\
(2.8) \\
\end{array}$ & \begin{tabular}{|l|}
87.3 \\
$(2.8)$ \\
\end{tabular} & \begin{tabular}{|l|}
82.7 \\
$(2.1)$ \\
\end{tabular} & $\begin{array}{l}81.7 \\
(3.2) \\
\end{array}$ & $\begin{array}{l}61.3 \\
(3.1) \\
\end{array}$ & $\begin{array}{l}56.5 \\
(3.7) \\
\end{array}$ & $\begin{array}{l}52.5 \\
(3.8) \\
\end{array}$ & $\begin{array}{l}48.8 \\
(5.3) \\
\end{array}$ & $\begin{array}{l}89.4 \\
(4.0)\end{array}$ & $\begin{array}{l}89.4 \\
(3.9) \\
\end{array}$ & $\begin{array}{l}89.5 \\
(4.3) \\
\end{array}$ & $\begin{array}{l}89.2 \\
(3.5) \\
\end{array}$ & $\begin{array}{l}87.1 \\
(4.3) \\
\end{array}$ & $\begin{array}{l}87.8 \\
(3.6) \\
\end{array}$ & $\begin{array}{l}88.3 \\
(4.2) \\
\end{array}$ & $\begin{array}{l}77.5 \\
(4.5)\end{array}$ \\
\hline
\end{tabular}


Table 3. Statistical analysis of flavourings in the four cell lines employed. All values relate to the Two-way ANOVA p-value result of that flavour compared to the strawberry viability data.

\begin{tabular}{|c|c|c|c|c|c|}
\hline \multirow[b]{2}{*}{ Cell line } & \multirow[b]{2}{*}{ Comparison flavour } & \multicolumn{4}{|c|}{ ECE concentration $(\%)$} \\
\hline & & 12.5 & 25 & 50 & 100 \\
\hline \multirow[t]{3}{*}{ IB3-1 } & Apple & 0.0001 & 0.01 & ns & 0.0001 \\
\hline & Cherry & 0.05 & $\mathrm{~ns}$ & 0.0001 & 0.0001 \\
\hline & Tobacco & $\mathrm{ns}$ & ns & 0.0001 & 0.0001 \\
\hline \multirow[t]{3}{*}{$\mathrm{C} 38$} & Apple & 0.0001 & 0.0001 & 0.0001 & 0.0001 \\
\hline & Cherry & $\mathrm{ns}$ & ns & 0.0001 & 0.0001 \\
\hline & Tobacco & 0.0001 & 0.0001 & 0.0001 & 0.0001 \\
\hline \multirow[t]{3}{*}{ BEAS-2B } & Apple & 0.0001 & 0.0001 & 0.0001 & 0.0001 \\
\hline & Cherry & 0.0001 & 0.0001 & 0.0001 & 0.0001 \\
\hline & Tobacco & 0.01 & 0.0001 & 0.0001 & 0.01 \\
\hline \multirow[t]{3}{*}{$\mathbf{J} 774$} & Apple & 0.01 & $\mathrm{~ns}$ & 0.0001 & 0.0001 \\
\hline & Cherry & ns & ns & 0.0001 & 0.0001 \\
\hline & Tobacco & 0.001 & ns & 0.0001 & 0.0001 \\
\hline
\end{tabular}




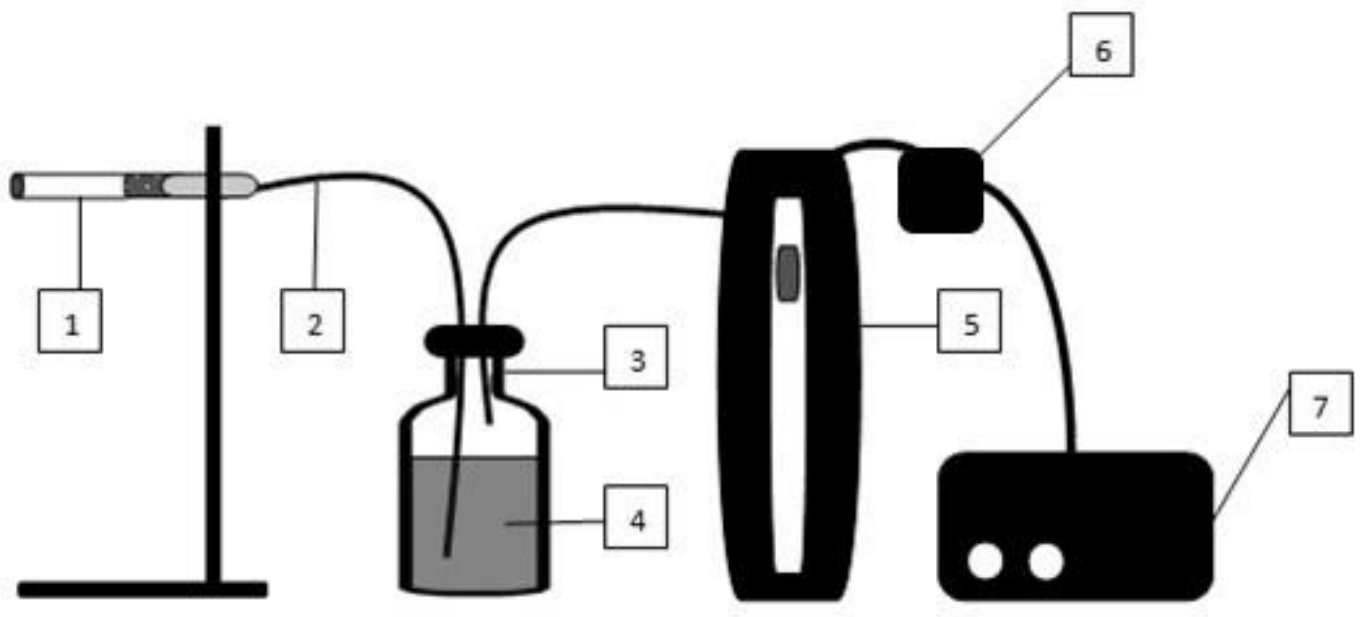

Figure 1. Schematic diagram illustrating the experimental set-up used to produce extracts. 


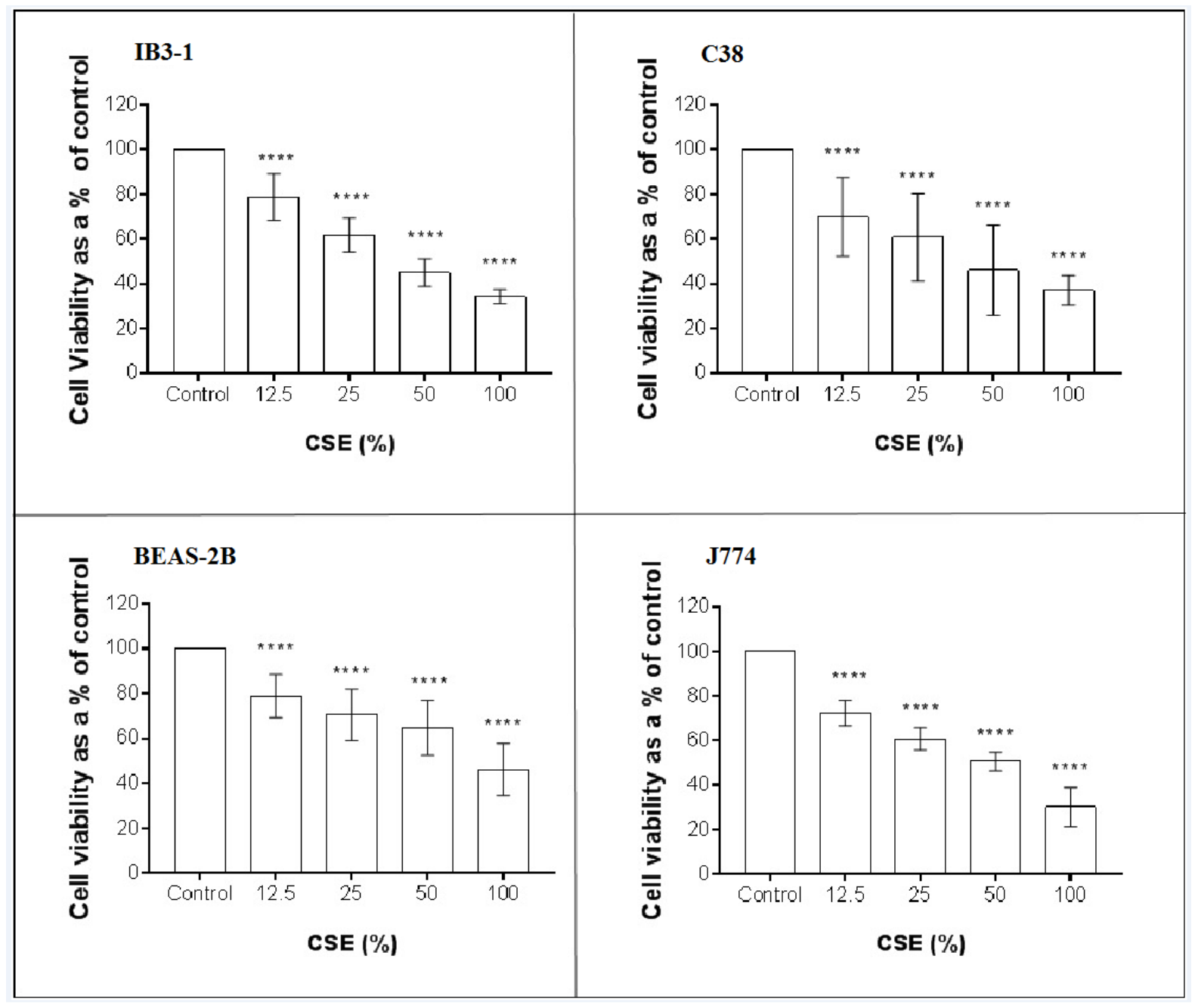

Figure 2. Effect of CSE on the viability of four different cell lines. 


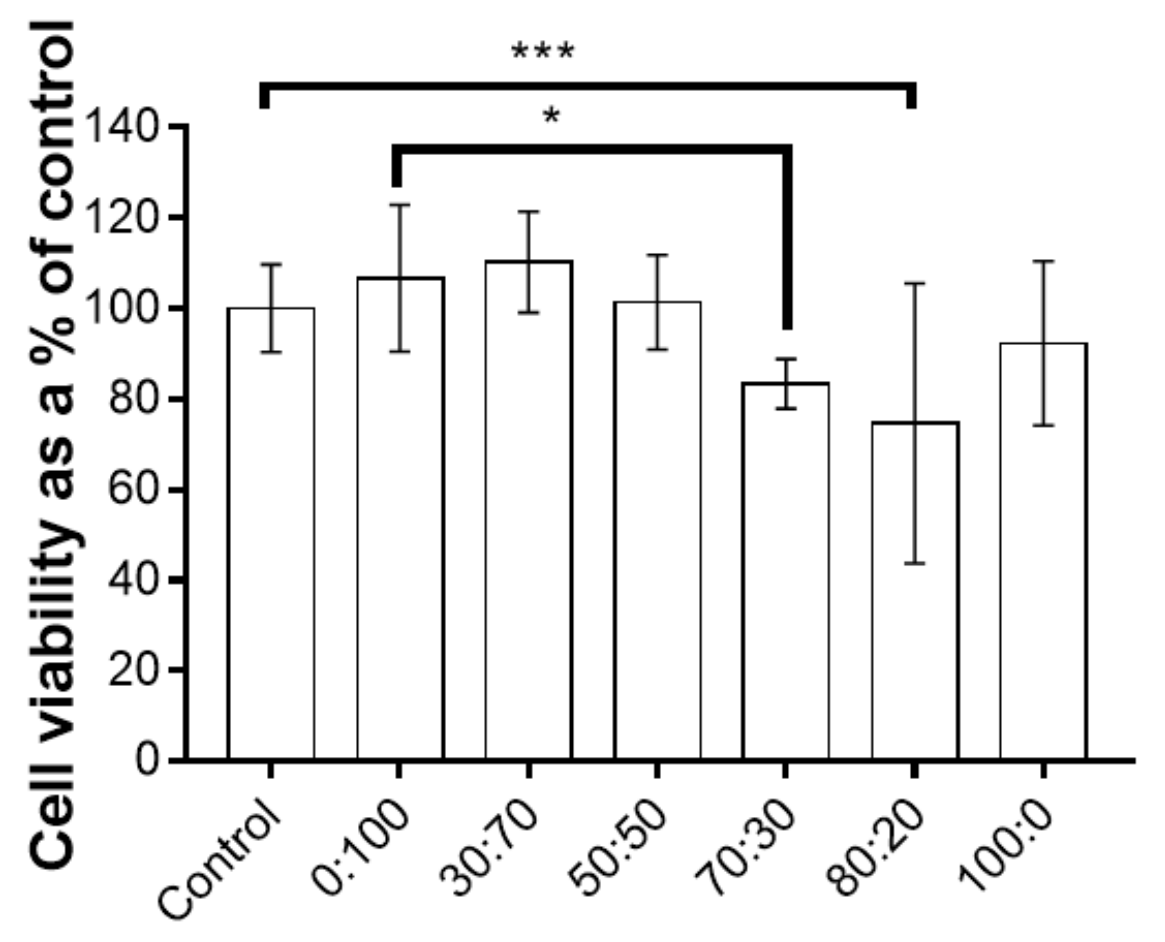

\section{Ratio of PG:G}

Figure 3. Effect of EVE on the viability of BEAS-2B. 


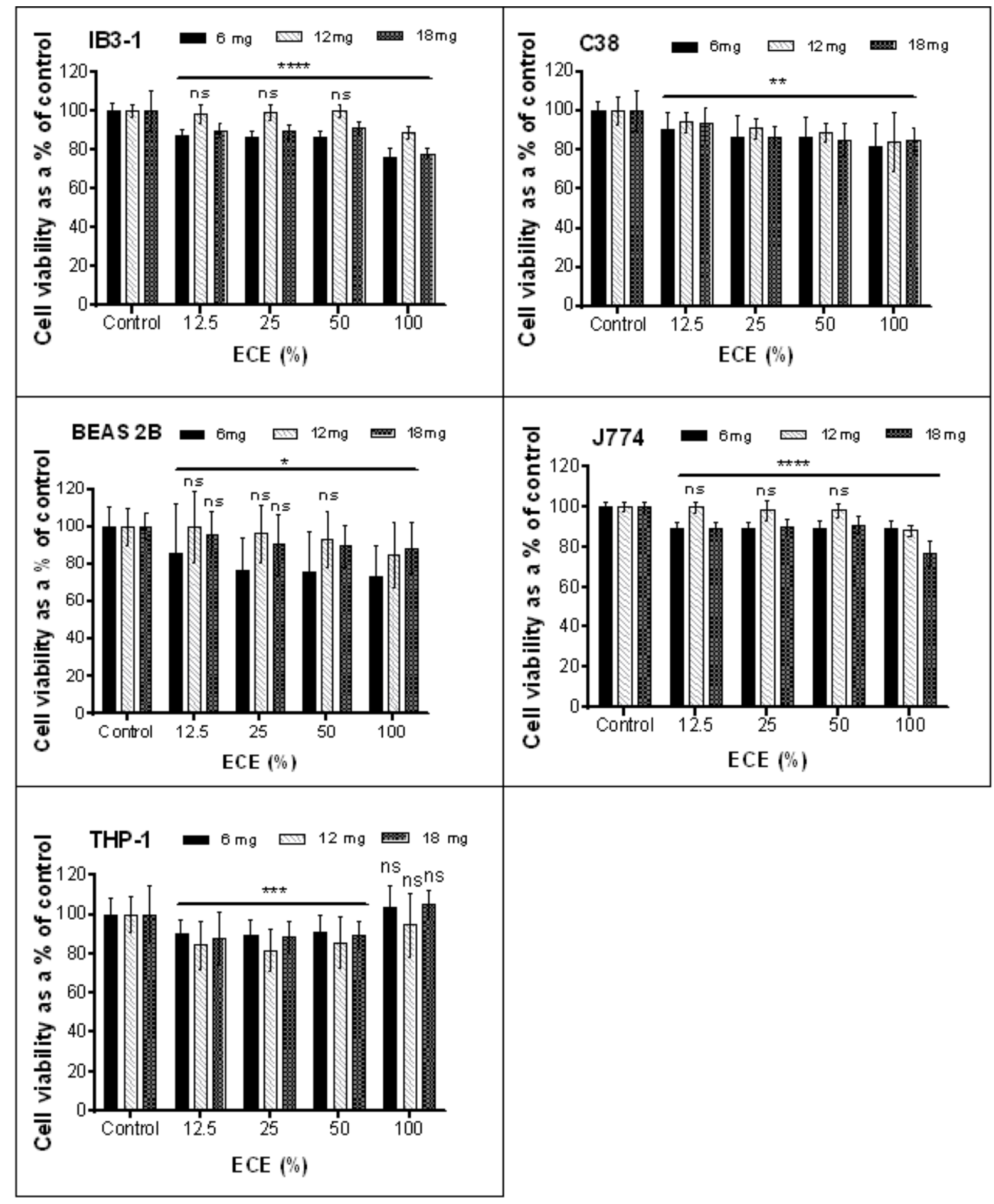

Figure 4. Effect of increasing concentrations of nicotine in ECE on cell viability. 


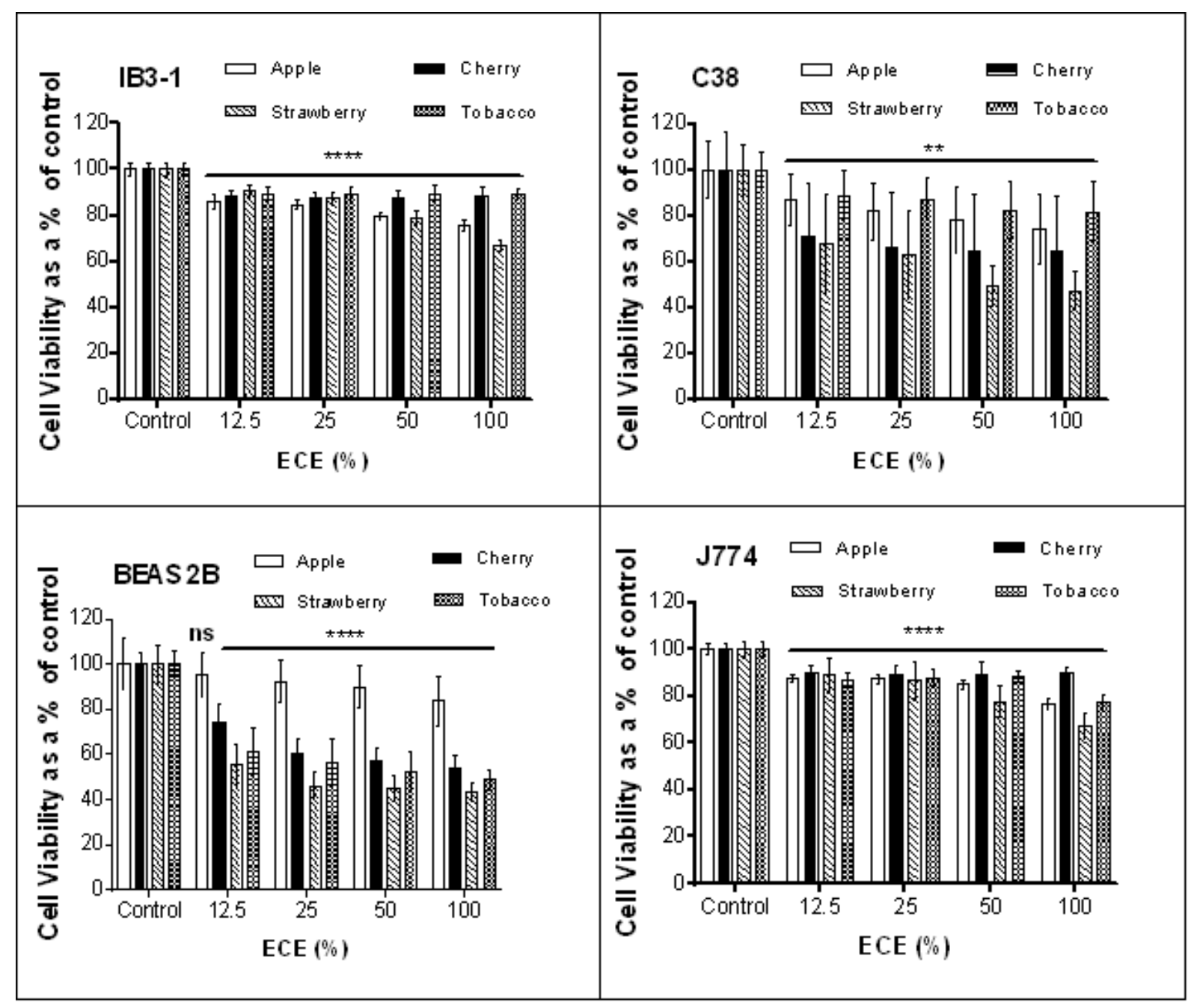

Figure 5. Effect of different flavours of ECE on cell viability. 


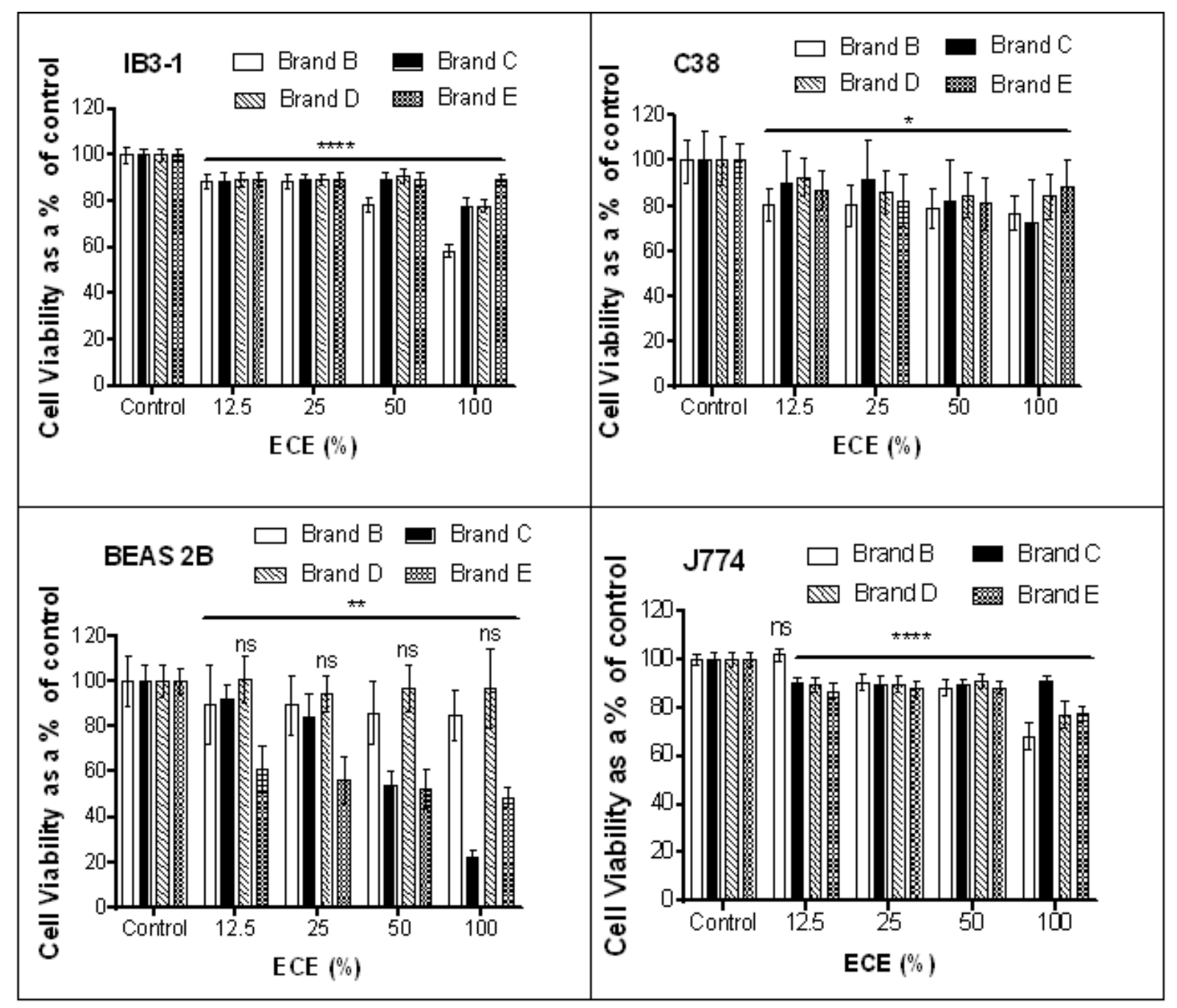

Figure 6. Effect of different brands of tobacco flavoured ECE on cell viability. 
Figure 1. CSE/ECE/EVE was prepared by bubbling the smoke/vapour from the cigarette or EC (1) through $10 \mathrm{~mL}$ of sterile culture medium (4). The sterile glass bottle (3) had an inlet tube (2) submerged in the medium to collect smoke/vapour and an outlet tube attached to the flow meter (5). A pump (6) attached to the power supply unit (7) was used to apply a vacuum for $2 \mathrm{~s}$ every $28 \mathrm{~s}$, drawing air through the cigarette/EC and thus pulling smoke/EC vapour into the medium. The extract medium was transferred into a new sterile bottle, prior to its dilution, where appropriate, and addition to cells.

Figure 2. CSE was prepared as described and diluted to 50, 25 and $12.5 \%$ in fresh sterile medium. $1 \mathrm{~mL}$ of the CSE was added to $3 \times 10^{5}$ cells $/ \mathrm{mL} /$ well of a 24 well plate and incubated for 24 hours, after which XTT was added to determine cell viability of IB3-1, C38, BEAS-2B and $\mathbf{J 7 7 4}$. Values are presented as the mean \pm 1 S.D. of four individual experiments, with quadruplicate wells per experiment. Cell viability is expressed as a percentage of the control (untreated cells). Statistically significant differences $(\mathrm{p}<0.0001)$ compared to the control and between each serial dilution were demonstrated for all four cell lines.

Figure 3. EVE was prepared as described at ratios of PG:G varying from 100:0 to 0:100. 1 $\mathrm{mL}$ of the EVE was added to $3 \times 10^{5}$ cells $/ \mathrm{mL} /$ well of a 24 well plate and incubated for 24 hours, after which XTT was added to determine cell viability. Values are presented as the mean \pm 1 S.D. of four individual experiments, with quadruplicate wells per experiment. Cell viability is expressed as a percentage of the control (untreated cells). The 80:20 ratio was significant compared to every other ratio including the control. Similarly, 70:30 ratio was significantly different from $0: 100,30: 70,50: 50$ but not the control, 80:20 and 100:0, as shown on the graph. All others were non-significant with respect to the control and other 
ratios $($ where $*=\mathrm{p}<0.05, * *=\mathrm{p}<0.01, * * *=\mathrm{p}<0.001, * * * *=\mathrm{p}<0.0001)$, however there was no ratio dependent effect.

Figure 4. Vapour from each EC of different nicotine content was extracted as described previously and added to IB3-1, C38, BEAS-2B, J774 and THP-1 cell lines. $1 \mathrm{~mL}$ of the ECE was added to $3 \times 10^{5}$ ( $2 \times 10^{5}$ for THP-1) cells $/ \mathrm{mL} /$ well of a 24 well plate and incubated for 24 hours after which XTT was added to determine cell viability. Values are presented as the mean \pm S.D. of four individual experiments, with quadruplicate wells per experiment. Cell viability is expressed as a percentage of the control (untreated cells). The minimum statistically significant differences are shown across each graph (where $*=p<0.05, * *=$ $\mathrm{p}<0.01, * * *=\mathrm{p}<0.001, * * * *=\mathrm{p}<0.0001$ ) between each ECE and the control (where ns is non-significant). There was no nicotine strength dependence effect.

Figure 5. IB3-1, C38, BEAS-2B and J774 cells were exposed to vapour extract from four different flavours of EC, with the same nicotine content $(16 \mathrm{mg} / \mathrm{mL}) .1 \mathrm{~mL}$ of the ECE was added to $3 \times 10^{5}$ cells $/ \mathrm{mL} /$ well of a 24 well plate and incubated for 24 hours after which XTT was added to determine cell viability. Values are presented as the mean \pm S.D. of four individual experiments, with quadruplicate wells per experiment. Cell viability is expressed as a percentage of the control (untreated cells). The minimum statistically significant differences are shown across each graph $($ where $*=\mathrm{p}<0.05, * *=\mathrm{p}<0.01, * * *=\mathrm{p}<0.001$, $* * * *=\mathrm{p}<0.0001)$ compared to control are shown for all four ECE tested (where ns is nonsignificant).

Figure 6. IB3-1, C38, BEAS-2B and J774 cells were exposed to ECE from four different brands of EC, all labelled as tobacco flavoured. $1 \mathrm{~mL}$ of the ECE was added to $3 \times 10^{5}$ 
cells/mL/well of a 24 well plate and incubated for 24 hours after which XTT was added to determine cell viability. Values are presented as the mean \pm S.D. of four individual experiments, with quadruplicate wells per experiment. Cell viability is expressed as a percentage of the control (untreated cells). The minimum statistically significant differences are shown across each graph $($ where $*=\mathrm{p}<0.05, * *=\mathrm{p}<0.01, * * *=\mathrm{p}<0.001, * * * *=$ $\mathrm{p}<0.0001$ ) compared to control are shown for all four ECE tested (where ns is nonsignificant). 